\title{
On the Concept of an Anatolian-Greek Language Area
}

\author{
Paola Cotticelli-Kurras \\ University of Verona, Verona, Italy \\ paola.cotticelli@univr.it
}

\begin{abstract}
This paper aims at presenting some thoughts on the hypothesis of an Anatolian-Greek language area in the second millennium вс comparing different approaches both in the theoretical frames and in the analysis of the linguistic facts. For this purpose, it is necessary to introduce some terminological premises, followed by a selection of methodological issues, which will help explore the putative features that characterize the Anatolian-Greek area (morphological traits such as actionality markers, particles, verbal prefixes as well as special morphological forms; morphosyntactic traits, such as modal particles, sentence particles, absolute participial constructions; lexical units and phonetic features).
\end{abstract}

\section{Keywords}

language league - language area - language contact - Indo-European Anatolian languages - Ancient Greek

\section{Some Terminological and Conceptual Preliminaries}

The birth of the debate concerning linguistic areas goes back to the nineteenth century, with specific reference to the work by Miklosich (1861) for the Balkan languages, and a few decades later to Baudouin de Courtenay (1904). In particular, the Neogrammarians - beside the development of the genealogical model based on shared hereditary traits - identified the problem that some languages shared traits that did not derive from a common matrix but rather from language contact, even if the study of these issues developed only in the 
twentieth century. Trubetzkoy (1928), following the Neogrammarians, introduced the classification of language groupings (Sprachgruppen) into two separate categories (language families or Sprachfamilien and language leagues or Sprachbünde; cf. Urban 2007: 140). He was followed by Jakobson (1931, 1938) (for phonological leagues), and then, with Weinreich (1958), interest in areal phenomena has intensively arisen until the last 40 years, with new insight into the classification of linguistic similarities and interchanges in certain cultural patterns.

In fact, since the first investigations in the 19th century have been carried out within an anthropological cultural agenda, already at the beginning of the 1990s linguist became more and more aware that many linguistic patterns and typological and historical features required areal explanations. This new born approach led to a better clarification of many of the issues involved and to the identification of several linguistic areas. ${ }^{1}$ Consequently, the dedicated investigations produced a very large literature. As regards the ancient times and regions, and specifically the Ancient Near-East, cultural and linguistic contacts became obvious in those situations where both related (i.e. belonging to the same family and/or branch) and unrelated languages interacted. Having rightly noted that many of the works on language contact have generally paid little attention to the distinction between the behaviors of related linguistic codes and non-related ones, Epp - Huehnergard - Pat-El (2013) introduced important observations on the similarities and dissimilarities of ancient language contact phenomena. The case studies involved Semitic and non-Semitic as well as Indo-European Anatolian languages. ${ }^{2}$ Only in recent years, the identification a so-called "Greek-Anatolian" area has been proposed, which would constitute yet another example of such a contact scenario. However, the case has not yet been within the framework of a language contact in the Ancient Near East. The identification of the particular case under discussion goes back to the famous study by Watkins (2001), which has given rise to a number of follow-up works. Before dealing with such this topic, however, some terminological as well as methodological issues will need to be tackled, in order to provide a grid of parameters which enable a solid discussion.

1 The main identified areas are: the Balkan language league (Birnbaum 1965, Joseph 1999), South Asian league, investigated by Masica (1976) who applied the principles of dialect geography mapping isoglosses that defined areas with a particular features, the North-East Asian league, Schönig (2003); Indian subcontinent, Emeneau (1956); the Ethiopian Language Area, Thomason (2000), the Caucasian Sprachbund, Tuite (1999) and Chirikba (2008); MesoAmerican linguistic area Campbell - Kaufmann - Smith-Stark (1986); Australian languages, Dixon (2001); and for ancient times the Sumerian and Akkadian language area (Deutscher 2007). For an overall presentation see Campbell (2017).

2 See Deutscher (2007). 
As a matter of fact, when we come to the matter of defining concepts such as 'linguistic area', 'linguistic league', 'Sprachbund', etc., in terms of language contact, the positions by several authors tend to remain vague. ${ }^{3}$ In defining a Sprachbund, scholars generally had no positive, shared criteria; rather, there is a tendency towards gathering common features that are specific to each situation and area. Nevertheless, in the conspicuous publications on this topic, theoretical models and various parameters have been proposed.

Therefore, in order to disambiguate the specificities of the different definitions of 'Sprachbund', 'language union', or 'area' and 'language / linguistic league' - the multiplication of the labels been often the result of metalinguistic translations - or again of 'convergence area' also with regard to the criterium of relatedness, a selection of chosen parameters will help clarify the differences (Table 1), (on relatedness criteria see Drinka 2013).

The history of these terms ${ }^{4}$ indeed shows how scholars have started from a definition of 'Sprachbund' as opposed to that of 'area of convergence', to eventually arrive at a superimposition or neutralization of the differences between them (Aikhenvald 2006). ${ }^{5}$

A few notes on some concepts will help to better highlight the differences in the mechanisms of diffusion of the features and of realization of the convergences.

Under the premise that "Mutual influence is what significantly distinguishes between a league and an ordinary two-language contact situation. In the latter the influence is usually unidirectional, i.e. there is no partnership" (Urban 2007: 141), we consider hence the concept and the dynamic of 'language league' as different from the case of 'borrowing' between languages in contact. Moreover, in a league the main innovations of shared features are: the development of a new trait, or its loss; the unexpected retention of an old trait, the lack of development of an expected one. In this sense, the conditions identified and described by McMahon - Matras - Vincent (2006: 669) are noteworthy, namely that the shared traits cannot be typologically prevalent worldwide; should emerge in most languages in an area; should not emerge in related languages or in other languages of the geographical area that is affected; should not be traits that too easily emerge in languages.

3 We refer to Urban, (2007: 137ff), who discuss in detail the differences between Sprachbund and language area.

4 See Campbell (2017) with further references.

5 As a complement to this first methodological portion of this work, it is useful to clarify that the choice to use the term 'linguistic area' depends also on the considerations by Schaller (1975) and Joseph (1992). 


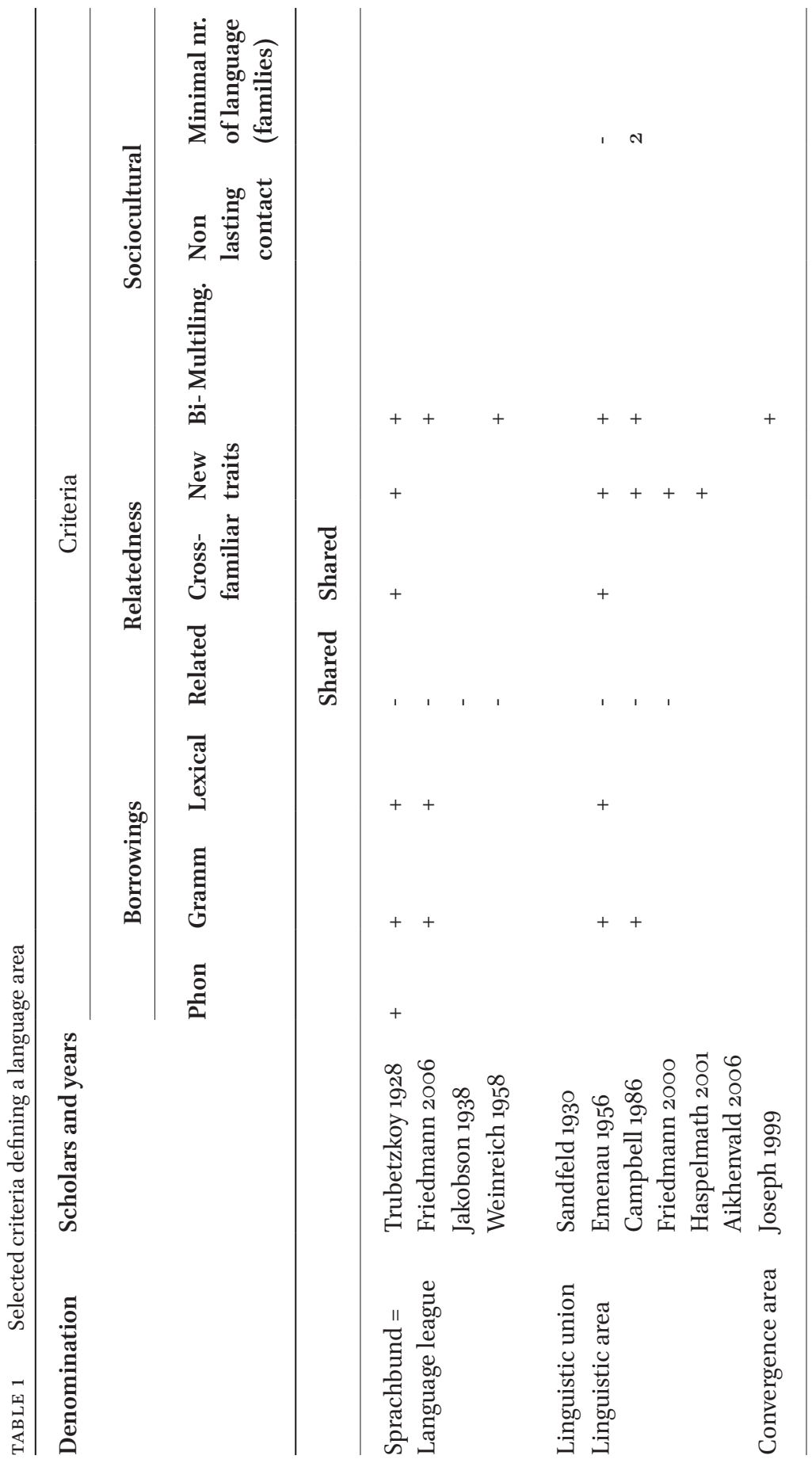


The term 'convergence' implies that the shared phenomena are a result of a mutual process of change among languages after a significantly long mutual exposition in specific geographic locations. 'Diffusion' on the contrary, is a term that merely refers to the mechanism of circulation of the shared trait or traits.

The presence of related and/or non-related languages has also an impact on the definition of linguistic areas and on the way they may originate, an issue that is not irrelevant to the discussion on the Anatolian-Greek area. Basing their discussion on the methodological impossibility to project family languages indefinitely into the past, some contemporary linguists such as Dixon (1997) assumed that both the birth of language families and the emergency of linguistic areas are viable scenarios that may have shaped the general geography of mutation. According to Dixon (1997), the dynamic of convergence may be applied even to the model of the genealogical tree. The model would include "unstable" periods, which Dixon defines in terms of "punctuation" and during which, due to minor or major movements of peoples, former "equilibria" collapse, resulting in a differentiation of the languages. On the other hand, there may be long phases of convergence, which end up producing a new proto-language. ${ }^{6}$ Such considerations, while highly stimulating, appear in any case more suitable for macro-comparatively investigating the formation of language families, and the possibility to specifically apply them to the Indo-European one remains matter of debate. (See Francois 2014).

In a similar fashion, Watkins (2001: 62f.) adds, when referring to the Indo-European linguistic history, that both the diffusion by contact and the language-internal change occur very quickly even during phases of stability. Equilibrium, according to Watkins, is therefore a "theoretical construct" that is conceivable, at latest, for the Paleolithic period, "where nothing much was going on" (2001: 62). Diffusion and convergence, for Watkins, follow dynamics and mechanisms different from the ones proposed by Dixon (1997), who, on the other hand, wrote: "[...] the formation and development of genetic families and the formation and development of linguistic areas [...] each [...] [has] its own dynamic, its own history, and its own life and fall. [...] Both [...] would have their own distribution of rapid and abrupt and slow gradual change [...]" (quoted from Watkins 20o1: 62, 63). In defining the history of the Indo-European languages, Watkins goes on stating that "the formation of diffusional linguistic areas is, on the one hand, relatively rapid (a matter of half a millennium or less), and, on the other, coexists with normal and relatively rapid genetic differentiations and the formation of species". As a response to

6 Dixon adds that: "The diatopic result of such phases can be studied only typologically, and the genealogical method is, in this case, useless". 
TABLE 2 Choice of available traits for a language area adapted from Cotticelli-Kurras Giusfredi 2018: 176

\begin{tabular}{lccccc} 
Features & Trubetzkoy & Greenberg & Haspelmath & Croft & Friedmann \\
& 1928,1931 & 1953 & 2001 & 2005 & 2006 \\
\hline $\begin{array}{l}\text { Phonetic units } \\
\text { Sound correspondences }\end{array}$ & & & & & + \\
$\begin{array}{l}\text { Lexical units } \\
\text { Morphological units }\end{array}$ & + & + & & & + \\
$\begin{array}{l}\text { Grammatical units } \\
\text { Form-only-criteria }\end{array}$ & + & + & + & & + \\
Meaning-only-criteria & & & & & \\
\hline
\end{tabular}

Dixon's statements, he remarks that the Indo-European examples show that both "contact-induced linguistic change (i.e. diffusion) and system-internally driven linguistic change may occur with equal abruptness and rapidity — thus both counting as 'punctuation'” (Watkins 2001: 62).

While not being able to offer a final solution to the clarification of the different metalinguistic terms and concepts pertaining to the areal phenomena and to the issue of their classification, it is tempting to suggest that the term "linguistic area' might define a static geographical situation (of equilibrium) where (both related and unrelated) languages interacted with each other through former or current migrations. The languages affected may share features, but these must not be the result of a shared and diffused language change.

As areas do involve shared traits, when trying to identify one it is also important to understand if there are types of features that are better predictors of proper areal dynamics. When comparing the views by a selected group of scholars, some differences emerge that are highlighted in Table 2.

The different positions by the scholars seem to carry to the conclusion that the common features to be analyzed need to be identified case by case. The following sections, after these initial, general considerations, will move on to the specific case of the problem of the so-called Greek-Anatolian areal contacts.

\subsection{A Methodological Debate}

A number of scholars (such as e.g. Puhvel 1991, Watkins 1997 onwards, followed in Italy by Lazzeroni 2006 and his school) proposed the existence of a Greek-Anatolian language area. The attempts were generally based on selected 
(putative) contact-induced changes, some of which will be discussed below. Also considering the genealogical relationship of the Greek language group and the Anatolian one, it is first necessary to face some specific questions:

2.1.1

What Are the Languages Involved within the Greek and Anatolian Groups?

The hypotheses in this regard can be divided into two main types of approaches:

- The first is represented by the hypothesis of involvement of a direct EasternGreek dialects - Hittite contact builds on the research by some scholars such as Puhvel (1991), Lazzeroni (2006), Bianconi (2015a, 2015b) and forthcomings, Romagno (2015);

- The second hypothesis is defended by scholars such i.e. Hajnal (2003, 2011, 2018), Gander (2010, 2021, i.p.), which paid more attention to the geo-historical collocation of the linguistic cultures in Bronze Age Anatolia and investigated the contacts between Luwic and Greek.

To this regard, some considerations are in order. From a historical and geographical viewpoint we can nowadays easily all agree that some forms of Greek - Western Anatolian language contacts should be certainly expected, as the main zone of interface (modern South Eastern Turkey) was probably Luwic speaking (see Hajnal 2018; Cotticelli-Kurras - Giusfredi 2018: 180). From a chronological perspective, it has been supposed that the two languages which were in such a contact-situation and developed contact-induced features may have been Mycenaean and Luwian (or other Luwic languages).

However, one should also concede that contacts between the Greek and the Hittite language are not to be excluded per se (see Gander, 2021, i.p.). In fact, Greek and Hittite historical contacts are documented by the existence of a diplomatic correspondence between Ahhiya(wa) and Hatti, with letters written in Hittite that were found in the archives of Hattuša. ${ }^{7}$ From a cultural viewpoint, we may certainly quote to Hajnal (2018), who writes: "Mycenaean Greeks are in contact with people of southwestern Asia Minor. From the point of view of cultural history, this fact is hardly surprising: Archaic Greek mythology and the Greek epics show similarities to Bronze Age sources from the Near East" (with reference to Burkert (2005: 292) in the footnote, to which we wish to add West $(1988,1997)$, also West (1978: 3-13) on Near Eastern influence in

7 For a comprehensive and detailed historical and geographical investigation we refer to the monography by Gander, (2021, i.p.) in which he discusses the identification of the since Forrer (1924) known Greek-Anatolian personal names, the historical background and the plausibility of the identification of geographical historical places, among them Wilusiya, Ahhiya(wa), and the boundaries of activities of the Hittite kings in the last decades of the Empire. See also Pantazis 20o9. 
Hesiod). The historical facts and questions are best left to the historian: see the discussion by Gander, loc. cit, especially Chapter 9.4, where the author affirms that research in recent years has neglected Cilicia as a possible contact place between Mycenaeans and Hittites and that the connection via western Anatolia and the Aegean was given a too high priority.

Whatever the details of the historical developments and events, for the second millennium вС there is generous documentation of the cuneiform texts from the Hittite archives. For the Greek one can rely only on the Mycenaean texts. However, these allow only limited insight into Bronze Age Greek. For this reason, records from the Homeric epics are consistently introduced in the discussion about Mycenaean-Anatolian language contacts. As for the choice to involve Luwian in the equation, this is based on the recent recognition (Yakubovich 2010) of the importance and large diffusion of the different varieties of Luwian (or, at least, of other Luwic languages) in Western and Southern Anatolia (a fact unknown in the mid twentieth century).

\subsection{A Discussion of Some Linguistic Data}

Mycenaean Greeks and Anatolians were in contact towards the end of the Bronze Age. These political and cultural contacts, however, do not immediately entail a scenario of language contact so intensive to justify the assumption of a language league. ${ }^{8}$ Most of the attested features, indeed have been discussed in literature in terms of what was the specific source language that modeled a change (an approach viable for the description of borrowing), but one should also investigate the type of contact scenario that may have produced the shared innovations.

Keeping in mind the table of features presented in Table 2, we can state that structural borrowings on a phonological, morphological or syntactical level generally occur in intense contact scenarios or, more locally, in a bilingual situation. The question is, hence, how can we prove whether or not this was the case when we come to the topic of the Aegean-Anatolian interface? Also: which direction took the language contact, which was the model language? Did it consistently occur from the Anatolian group to the Greek one (as many studies seem to assume) or vice versa? Which are the possible comparanda, or, again, what are the linguistic documents one may compare? And finally, which are the features involved within the Greek and Anatolian groups?

8 To this point we quote Oreshko (2018), though his conclusion is here not fully shared since the non-shared lexical borrowings do not automatically lead to the non borrowability in the domains of morphology and syntax. 
After an initial review of the available literature, the hypotheses can also in this case be divided based on the two main approaches. Both approaches (Greek and Hittite relations vs Mycenaean and Luwian contact) take into consideration both the lexical and phraseological events as also the systematic contact-induced ones (including units of the morphological, grammatical and syntactic layers, see Dardano 2012 and 2013). However, the central question remains: do the considered phenomena emerging in related but different languages depend on contact, or can common inheritance or typological prevalence have played a role?

In Table 3 below, the peculiar and most striking features from the Greek an Anatolian corpora discussed in the quoted works by Puhvel, Watkins, Lazzeroni and Romagno are organized based on the traits listed above in Table 2. The following picture leads to the conclusion that those features are not exclusive traits of a contact-induce changes, but they might, in general, be explained as inherited structures.

In the next section, a selected group of the traits which were used to propose a Greek-Anatolian area, will be briefly discussed.

TABLE 3 Main traits of the Anatolian language area, partially based on Cotticelli-Kurras Giusfredi 2018: 181

\begin{tabular}{|c|c|c|c|c|}
\hline Type & Hittite & Luwian & Greek & Feature type \\
\hline Assibilation prs3sg & + & - & $\begin{array}{l}\text { Partially } \\
\text { Eastern } \\
\text { dialects }\end{array}$ & Phonetic units \\
\hline Modal particles & + & - & + & $\begin{array}{l}\text { Grammatical } \\
\text { units }\end{array}$ \\
\hline $\begin{array}{l}\text { Inanimate-only } \\
\text { allative }\end{array}$ & + & No allative & + & $\begin{array}{l}\text { Form and } \\
\text { meaning } \\
\text { criteria }\end{array}$ \\
\hline Absolute participle & $\begin{array}{l}\text { Seldom } \\
\text { structures }\end{array}$ & - & + & $\begin{array}{l}\text { Grammatical } \\
\text { units }\end{array}$ \\
\hline $\begin{array}{l}\text { Prefixation for } \\
\text { telicity }\end{array}$ & $\begin{array}{l}\text { Other } \\
\text { elements }\end{array}$ & - & + & $\begin{array}{l}\text { Form and } \\
\text { meaning } \\
\text { criteria }\end{array}$ \\
\hline Past-sk(e)-forms & + & $\begin{array}{l}\text { Other } \\
\text { morphems }\end{array}$ & $\begin{array}{l}\text { Homer, later } \\
\text { rarely }\end{array}$ & $\begin{array}{l}\text { Morphological } \\
\text { units }\end{array}$ \\
\hline
\end{tabular}


Morphological Traits (Actionality, Particles,) as Form and Meaning and Morphological Units Criteria

\subsubsection{Morphological Traits}

The verbal endings -men vs. -mos for the 1 pers. Pl. in a complementary distribution both in the IE languages and among the Greek dialects since the Doric -mes ending (attested also in Latin, Sanskrit, and in the Baltic languages) represent one of the criteria for the dialectal or diatopic and diachronic categorization of the Greek dialects, as Ionic and Attic exhibit a variant -men, which is related to the ending present in Anatolian languages. Since Rix $\left(1976,243^{f}\right.$. § 268 and 251f. § 274), the isogloss mirrors the distribution of the reconstructed forms for the $1 \mathrm{pl}$. *-mes for the primary active endings and *-me for the secondary stative ones, whereby the ending *-me also attested in Vedic - $m a$, received the $-n$ element in Greek and in Hittite. This distribution may very well reflect rather a geographical behavior of inherited and partially shared traits in earlier phases of the development of Indo-European than demonstrate that it occurred by contact during historical times.

As for the other allegedly shared morphological unit, the verbal suffix -sk-, common Indo-European inheritance is a solid explanation and grammatical interference does not need to be postulated (cf. the discussion in Cambi 2007 and Daues 2009).

2.2.2 Morphosyntactic Traits (Modal Particles, Sentence Particles, Verbal Prefixes) as Grammatical Units Criteria

2.2.2.1. Hittite verbal prefixation, often considered to be a shared feature, is not comparable with the same phenomenon in Ancient Greek. First of all the verbal "prefixation" is a category that is undergoing constant change in Hittite, since the involved verbs do generally not display compounds and the "preverb" could still work as an adverbial element. Secondly, non-inherent telicity is mostly expressed in Hittite through the particle -kan, which has no relevant counterpart in Greek. A very clear example is given by the Hittite verb simple kuen- 'to hit' vs. kuen- + -kan 'to kill'. ${ }^{9}$ Moreover, verbal prefixes can encode telicity also in other Indo-European languages, like the German ones, which

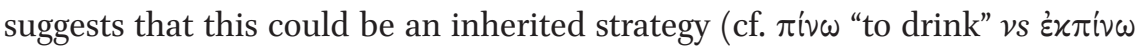
"to drink up" and German trinken vs. austrinken "to drink" vs "to drink up/completely"; cf. also Romagno 2015: 7 ff.).

2.2.2.2. Modality could be encoded through particles as well as through other morphological devices. Hittite had only two finite moods (the Indicative and Imperative), which means that the subjunctive and optative moods were

9 I refer to Cotticelli-Kurras (2014). 
not available. The past tense in combination with the particle -man (ma-an or $m a-n=)$ was hence employed to convey a contra-factual meaning as well as a potential one (s. Romagno 2015: 6f.). Hittite man has been compared with gr. $\dot{\varepsilon} \alpha \nu$ and $\alpha \dot{\alpha}$, (see Beck et al. 2012), from a functional viewpoint, but the Greek particles are syntactically dependent on the use of a morphological optative mood, which is unavailable in Hittite. All in all, the comparison is quite weak.

Furthermore, in Hittite, the particle is always required in order to convey the modal meaning (in any type of clause, either main or subordinate). This is not the case in Homeric Greek.10 Below, I quote a potential optative and a counterfactual indicative, both without a modal particle but with modal meaning.

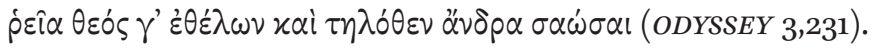

"Easily, a god could save a man even from afar, if he so wishes."

In this instance the optative $\sigma \alpha \omega \sigma \alpha \iota$ has potential meaning, and yet no modal particle has been used.

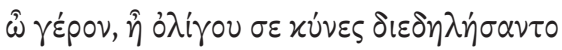

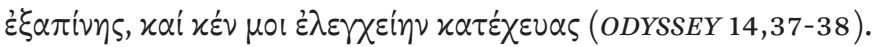

$$
\begin{aligned}
& \text { "Old man, suddenly, the dogs had almost torn you into pieces and you } \\
& \text { would have brought great shame on me." }
\end{aligned}
$$

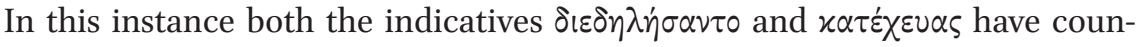
terfactual meaning, but in the first instance this meaning is signalled by o $\partial i$ irov "almost" and in the second instance by the modal particle $x \varepsilon v$.

Finally, when comparing the modal particle use in Hittite with that in Greek, scholars have traditionally used Attic Greek as comparandum, but there is a substantial geographical and chronological difference between Hittite (XVII - XII BC) and Attic Greek (V - IV BC) and, contrary to Ionic and the Western Anatolian languages, neither of them has ever been geographically contiguous in historical times. Apart from this, it is also noteworthy that the use of the modal particle in Attic Greek is rigidly regulated (as result of a grammaticalisation process), but this is not (yet) the case for epic Greek, in which the particle seems to have a more deictic value and not a proper modal meaning. ${ }^{11}$

10 For the Greek modal particles and their uses, see De Decker, i.p. and Palmer 1986. In general, on Mycenaean see Bartoněk (2003).

11 I discussed the topic with Filip De Decker, who is carrying out a Marie Curie research on modality in comparison between Greek and Hittite. On modality in Hittite, see Lühr (2001). 


\subsubsection{Absolute Participial Constructions}

Since Romagno 2015: 1of. brought this example as an open question regarding the possibility to be a shared trait of the Anatolian-Greek language contact, it is worth noting that in the whole Hittite tradition there are only four known examples of a so-called absolute participial construction, and all of them are referred to the same two verbs ('to stay' and 'to sit'), written in their sumerographic form, GUB and TUŠ respectively, in the phrases: 'the king sitting/staying, libates (the gods)'. These isolated forms are still debated in the literature ${ }^{12}$ and it is not possible to compare their function (maybe participium conjunctum) with that of the Greek absolute participle construction with the genitive. It can, therefore, hardly be considered a shared trait. Furthermore, the Genitive Absolute (GA) might very well have originated within Greek itself, being and independent phenomenon, perhaps starting from constructions in which the subject of the GA was first an object of a verb of the main clause, after which the construction grammaticalised into an independent syntagma. In epic Greek we find examples of both. For a detailed analysis, see Classen (1879: 134-188) and Ruppel (2013). ${ }^{13}$

\subsubsection{Phonetic Features}

Assibilation in Anatolian was thoroughly described by Kloekhorst 2008, ED HIL: 91f., and its counterpart represents a new classificatory element for the categorization of the Greek dialects (northwest vs. (south) east).

Regarding the phenomenon of the constraints of assibilation, the ending of the 3 rd person sg. *- $t i$ becomes - $z i$ in Hittite and $-\sigma \iota$ in the Greek dialects of the Circum-Aegean area, i.e. Ionic-Attic, Lesbian, Mycenaean and ArcadianCypriot; Hittite <z> probably represents an affricate (Kronasser, 1955: 61) and in Greek $-\sigma \mathrm{l}$ the sibilant outcome implies an affricate stage (see Romagno 2015: 4).

This phenomenon has been considered a possible shared feature. BUT it is worth noting that the corresponding Luwian isogloss in a direct neighboring context retains - $t i$ and does not share the innovation: affrication before final /i/ is, indeed, merely a Hittite sound change. This forces us to doubt the areal connection because of the geographical distance and the unlikelihood of direct contact.

12 See beside Hoffner - Melchert (2008) with previous references, Frotscher (2013), Cotticelli Kurras (2017: 21ff.), Even if one of the quotations could be interpreted as a genitive participle, the structure is not a so-called "absolute" one because both verbs, the participle and the finite verb of the main sentence, refer to the same subject.

I thank Filip De Decker for this bibliographical reference. 


\subsection{The Distribution of Selected Features: An Overview}

All in all, considering also the other direction of the language contact, from Anatolian to Mycenaean, based on Hajnal's discussion (2018) we can describe the following alleged phenomena in the given distribution (Table 4):

TABLE 4 Distribution of the features of a putative Anatolian-Greek area

\begin{tabular}{|c|c|c|c|c|}
\hline Туре & Hittite & Luwian & Greek & Feature type \\
\hline $\begin{array}{l}\text { Loan words (cultural } \\
\text { terms) }\end{array}$ & + & - (rare) & - (rare) & Lexical units \\
\hline $\begin{array}{l}\text { Phraseological } \\
\text { parallels }\end{array}$ & + & $+/-$ & + & Lexical units \\
\hline $\begin{array}{l}\text { Particles (Hom. -tar } \\
\text { and C-Luw. -tar) }\end{array}$ & $\begin{array}{l}- \\
\text { (= -san with } \\
\text { locative } \\
\text { meaning) }\end{array}$ & $\begin{array}{l}+ \\
\text { Sentence } \\
\text { particles (at } \\
\text { the end of } \\
\text { clitic string) }\end{array}$ & $\begin{array}{l}+ \\
\text { (Wackernagel } \\
\text { position) } \\
\text { discourse } \\
\text { particle }\end{array}$ & $\begin{array}{l}\text { Grammatical } \\
\text { units }\end{array}$ \\
\hline $\begin{array}{l}\text { Adjectives of } \\
\text { possession } \\
\text { ending in /-io-/and } \\
\text { adjectives of matter } \\
\text { in /-eyo- }\end{array}$ & - & - & $\begin{array}{l}+ \\
\text { (Lesbian as an } \\
\text { independent } \\
\text { archaism) }\end{array}$ & $\begin{array}{l}\text { Form-only- } \\
\text { criteria }\end{array}$ \\
\hline $\begin{array}{l}\text { Possessive adjective } \\
\text { ending in } *-\text {-io- } \mid> \\
i \text {-stems }\end{array}$ & $\begin{array}{l}\text { Other } \\
\text { elements }\end{array}$ & + & $\begin{array}{l}\text { - } \\
\text { Hellenistic in the } \\
\text { period) }\end{array}$ & $\begin{array}{l}\text { Morphological } \\
\text { units }\end{array}$ \\
\hline $\begin{array}{l}\text { Accusativus } \\
\text { graecus }^{14}\end{array}$ & $\begin{array}{l}+ \\
\text { (religious/ } \\
\text { poetic } \\
\text { language) }\end{array}$ & $\begin{array}{l}+ \\
\text { (religious/ } \\
\text { poetic } \\
\text { language) }\end{array}$ & $\begin{array}{l}\text { Homer, later } \\
\text { rarely }\end{array}$ & $\begin{array}{l}\text { Form and } \\
\text { meaning criteria }\end{array}$ \\
\hline
\end{tabular}

\section{Summing Up on the Greek-Anatolian Area}

The hypothesis of an Anatolian-Greek language area has been a much debated one, also for theoretical reasons. First of all, it is often treated as an area consisting of only two related languages, though, in fact, the reference to "Hittite"

14 For the accusativus graecus see also the discussion in Smyth-Messing (1956: 36o-361) where it is catalogued under "The Free Uses of the Accusative". It exists in Attic Greek, but is used very limitedly. 
should often be replaced by a wider reference to the languages of the Anatolian group. Indeed, direct Hittite-Greek language contact is unlikely to have happened for geographical and chronological reasons. Still, the phenomena analysed were often typical of Hittite but not of the Luwian language, or vice versa, which represents an obvious problem.

Another anomaly is represented by the direction of the supposed shared phenomena, which seems to be unidirectional. Thus, scholars systematically tried to find influence from Anatolian (i.e. Hittite) to Greek, ignoring the opposite direction. For the importance of mutual influence in areal contexts, see also Campbell (1985: 20f., and 2006). Finally, as already highlighted in the work by Hajnal (2018) Anatolian appears to be consistently the putative source language, with little or no trace of mutual influence within the alleged area. Hajnal and Gander $(2003,2011)$ do not exclude all kinds of Mycenaean-Anatolian contacts, but assumes that they may have existed only for a limited period of time and in a localized geographical region. (On the Ahhiyawa-debate see Fischer 2010).

Summing up, if we check the above mentioned linguistic traits, we can conclude, concerning the Greek-Anatolian area, that:

a. Some traits are indeed typologically common to many languages in the world;

b. The alleged shared traits emerged only in part of the languages of the area;

c. Other languages that belong to the same (Indo-European) family of those involved also share some traits.

In light of these considerations, it appears that the available evidence may call for some cases of interference between Western Anatolian and the Greek languages, but does not justify the hypothesis of a language league.

\section{References}

Aikhenwald, A.Y. - Dixon R.M.W. (eds.), 2006, Grammars in contact. A cross-linguistic Typology, (Explorations in Linguistic Typology), Oxford: Oxford University Press.

Bartoněk, A. 2003, Handbuch des mykenischen Griechisch, Heidelberg: Winter.

Baudouin de Courtenay, I.A. 1904, Jazykoznanie (Linguistics), in Brockhaus F.A - I.A. Efron (eds.), Enciklopedičeskij slovar': 31.

Beck, J.E. - Malamud, S.A. - Osadcha, I. 2012, A Semantics for the Particle äv in and outside Conditionals in Classical Greek, «JGL» 12: 51-83.

Bianconi, M. 2015a, Alle fonti di Elle. Contatti linguistici greco-anatolici nel secondo millennio a.e.v., MA thesis, University of Pisa. 
Bianconi, M. 2015b, Contattigreco-anatolici e Sprachbund egeo-micrasiatico. Stato della ricerca e nuove prospettive, «AGI» 100/2: 129-178.

Birnbaum, H. 1965, Balkanslavisch und Südslavisch. Zur Reichweite der Balkanismen im südslavischen Sprachraum, «ZfB» 3: 12-63.

Burkert, W. 2005, Near Eastern connections, in J.M. Foley (ed.), A Companion to Ancient Epic, Malden: MA 291-301.

Cambi, V. 2007, Tempo e aspetto in ittito con particolare riferimento al suffisso -ske/a-:. Alessandria: Edizioni dell'Orso.

Campbell, L. 1985, Areal linguistics and its implications for historical linguistic theory, in J. Fisiak (ed.), Proceedings of the Sixth International Conference of Historical Linguistics, Amsterdam: John Benjamins: 25-56.

Campbell, L. 2006, Areal Linguistics: A Closer Scrutiny, in Matras, Y. et al. (eds.), Linguistic Areas, Palgrave Macmillan: 1-31.

Campbell, L. 2017, Why is it so Hard to Define a Linguistic Area? In R. Hickey (ed.), The Cambridge Handbook of Areal Linguistics (Cambridge Handbooks in Language and Linguistics), Cambridge: Cambridge University Press: 19-39. doi:10.1017/9781107279872.003.

Campbell, L. - Kaufman, T. - Smith-Stark, Th.C. 1986, Meso-America as a linguistic area, «Language» 62: 530-570.

Chirikba, V. A. 2008, The problem of the Caucasian Sprachbund, in Muysken, P. (ed.), From linguistic areas to areal linguistics, Amsterdam-Philadelphia:John Benjamins: 25-94.

Classen, J. 1879, Beobachtungen über den homerischen Sprachgebrauch, Frankfurt: Winter: $134-188$.

Cotticelli Kurras, P. 2014, Interaktion zwischen semantischen Verbalklassen und syntaktischen clusters, in P. Taracha - M. Kapełuś (eds.), Proceedings of the Eighth International Congress of Hittitology, Warsaw 5-9 September 2011, Warsaw: Agade: 202-215.

Cotticelli Kurras, P. - Giusfredi, F. 2018, Ancient Anatolian languages and cultures in contact: some methodological observations, «JoLR» (Journal of Language Relationship) 16: 172-193.

Croft, W. 2005, Editor's introduction, in J.H. Greenberg, Genetic linguistics. Essays on theory and method, Oxford: Oxford University Press: xi-xxxvi.

Dardano, P. 2012, Il vento, i piedi e i calzari: i messaggeri degli dei nei miti ittiti e nei poemi omerici, in N. Bolatti-Guzzo - S. Festuccia - M. Marazzi (eds.), Centro mediterraneo preclassico. Studi e ricerche, III. Studi vari di egeistica, anatolistica e del mondo mediterraneo, Napoli: Università degli Studi Suor Orsola Benincasa: 53-87.

Dardano, P. 2013, Lingua omerica e fraseologia anatolica: vecchie questioni e nuove prospettive, in M. Mancini - L. Lorenzetti (eds.), Le lingue del Mediterraneo antico. Culture, mutamenti, contatti, Firenze: Carocci: $125^{-15}$. 
Daues, A. 2009, Zum Funktionsbereich des Suffixes *-ske/o- im Junghethitischen und Homerischen, in Lühr, R. - Ziegler, S., Protolanguage and Prehistory. Akten der 12. Fachtagung der Indogermanischen Gesellschaft in Krakau, 11.-15. Okt. 2004, Wiesbaden: Reichert: 82-99.

De Decker, F. ftc., A look at some (alleged) morpho-syntactic isoglosses between Greekand Anatolian: the modal particle in epic Greek. To appear in Giusfredi, F. - Zsolt, S. Simon (eds.), Studies in the languages and language contact in Pre-Hellenistic Anatolia, with the editorial assistance of Elena González Martínez, Barcino Monographica Anatolica, Barcelona: Publicacions i Edicions U B.

Deutscher, G. 2007, Syntactic Change in Akkadian: The Evolution of Sentential Complementation, Oxford: Oxford University Press: 20-21.

Dixon, R.M.W. 1997, The Rise and Fall of Languages, Cambridge: Cambridge University Press.

Dixon, R.M.W. 2001, The Australian Linguistic Area, in Dixon, R.M.W - Aikhenvald, A. (eds.), Areal Diffusion and Genetic Inheritance: Problems in Comparative Linguistics, Oxford University Press: 64-104.

Drinka, B. 2013, Phylogenetic and areal models of Indo-European relatedness: The role of contact in reconstruction, «Journal of Language Contact» 6: 379-410.

Emeneau, M. 1956, India as a Linguistic Area, «Language» 32/1: 3-16, doi: 10.2307/410649.

Epps, P. - Huehnergard, J. - Pat-El, N. 2013 (eds.), Introduction: Contact Among Genetically Related Languages, (Special Issues) «Journal of Language Contact»6: 209-219.

Fischer, R. 2010, Die Ahhijawa-Frage: Mit einer kommentierten Bibliographie, Harrassowitz: Wiesbaden.

Forrer, E. 1924, Die Griechen in den Boghazköi-Texten, «OLZ» 27: 113-118.

Francois, A. 2014, Trees, waves and linkages. Models of language diversification, The Routledge Handbook of Historical Linguistics, London-New York: Routledge: 161-189.

Friedman, V.A. 2000, After 170 years of Balkan linguistics: Whither the millennium? «Mediterranean Language Review» 12: 1-15.

Friedman, V.A. 2006, Balkans as a linguistic area, in K. Brown (ed.), Elsevier Encyclopedia of Language and Linguistics, Oxford: Elsevier: 657-672.

Frotscher, M. 2013, Das hethitische -ant-Partizip und seine indogermanischen Grundlagen: Semantik, Morphologie, Syntax, Doctoral Dissertation, Università degli Studi di Verona.

Gander, M. 2010, Die geographischen Beziehungen der Lukka-Länder, Winter Universitätsverlag: Heidelberg.

Gander, M. 2012, Ahhiyawa - Hiyawa - Que: Gibt es Evidenz für die Anwesenheit von Griechen in Kilikien am Übergang von der Bronze- zur Eisenzeit?, «SMEA» 54 (2012 [2013]): 281-309. 
Gander, M. 2021 (i.p.), Geschichte und Geographie Westkleinasien, (Texte der Hethiter 31), Winter: Heidelberg.

Greenberg, J.H. 1953, Historical linguistics and unwritten languages, in A. L. Kroeber (ed.), Anthropology today, Chicago: University of Chicago Press: 265-86.

Hajnal, I. 2003, Troia aus sprachwissenschaftlicher Sicht:die Struktur einer Argumentation, Institut für Sprachen und Literaturen der Universität Innsbruck: Innsbruck.

Hajnal, I. 2011, Namen und ihre Etymologien - als Beweisstücke nur bedingt tauglich?, in U. Christoph, - Rollinger R., (Hg.), Lag Troia in Kilikien? Der aktuelle Streit um Homers Ilias, Wissenschaftliche Buchgesellschaft: Darmstadt 2011, 241-263.

Hajnal, I. 2018, Graeco-Anatolian contacts in the Mycenaean period, in J. Klein B. Joseph -M.A. Fritz (eds.), Handbook of Comparative and Historical Indo-European Linguistics, Bd. 41/3 (Handbücher zur Sprach- und Kommunikationswissenschaft / Handbooks of Linguistics and Communication Science (HSK)), 2O37-2055, https:// doi.org/10.1515/9783110542431-041.

Haspelmath, M. 2001, The European linguistic area: Standard Average European, in M. Haspelmath - E. König - W. Oesterreicher - W. Raible (eds.), Language typology and language universals: an International handbook, Berlin: De Gruyter: 1492-1510.

Hoffner, H.A. - Melchert, H.C. 2008, A Grammar of the Hittite Language, Winona Lake: Eisenbrauns.

Jakobson, R. 1931, Über die phonologischen Sprachbünde, «Travaux du cercle linguistique de Prague» 4: 234-240.

Jakobson, R. 1938, Sur la théorie des affinités phonologiques entre les langues, in Actes du quatrième congrès international de linguistes tenu à Copenhague du 27 aout au rer septembre, 1936, New York: Kraus Reprints: $355^{-365}$.

Joseph, B. 1992, The Balkan languages, in, Bright W., International Encyclopedia of Linguistics, vol. 1, Oxford: Oxford University Press: 153-155. (Revised version in 2nd edition, 2003 ed. by W. Frawley).

Joseph, J. 1999, Romanian and the Balkans: Some comparative perspectives, in S. Embleton - J. Joseph - H.-J. Niederehe (eds.). The emergence of the modern languages sciences. Studies on the transition from historicalcomparative to structural linguistics in honours of E.F.K. Koerner. II Methodological perspectives and applications, Amsterdam - Philadelphia: John Benjamins: 218-235.

Josephson, F. 1972, The Function of the Sentence Particles in Old and Middle Hittite, Uppsala: Skriv Service Ав.

Kloekhorst, A. 2008, Etymological Dictionary of the Hittite Inherited Lexicon, (EDHIL), Leiden - Boston: Brill.

Kronasser, H. 1955, Vergleichende Laut- und Formenlehre des Hethitischen, Heidelberg: Winter. 
Lazzeroni, R. 2006, La codifica dell'allativo in greco e in ittita. Contributo allo studio di un'area linguistica circumegea, «AGI» 91: 106-111.

Lühr, R. 2001, Zum Modalfeld im Hethitischen, in O. Carruba - W. Meid (eds.), Anatolisch und Indogermanisch. Akten des Kolloquiums der Indogermanischen Gesellschaft, Pavia, 22.-25 September 1998, Innsbruck: Innsbrucker Beiträge zur Sprachwissenschaft: 239-262.

Masica, C.P. 1976, Defining a linguistic area: South Asia, Chicago: University of Chicago Press.

Matras, Y. - McMahon, A. - Vincent, N. 20o6, Linguistic Areas: Convergence in Historical and Typological Perspective, MacMillan Palgrave: Oxford.

Miklosich, F. 1861, Die slavischen Elemente im Rumunischen, «Denkschriften der Kaiserlichen Akademie der Wissenschaften, Philosophisch-historische Klasse» 12: $1-70$.

Oreshko, R. 2018, Anatolian linguistic influences in Early Greek (1500-80o BC)? Critical observations against sociolinguistic and areal background, «JoLR» (Journal of Language Relationship) 16/2: 93-118.

Palmer, F.R. 1986, Mood and Modality, Cambridge: Cambridge University Press.

Pantazis, V. D. 20o9, Wilusa: Reconsidering the Evidence, «Klio» 91/2: 291-310.

Puhvel, J. 1991, Homer and Hittite, Innsbruck: Institut für Sprachwissenschaft der Universität Innsbruck.

Romagno, D. 2015, The Greek-Anatolian area in the 2nd millennium B.C.: between language contact, Indo-European inheritance and typologically natural tendencies, «SSL» 53: 429-446.

Ruppel, A. 2013, Absolute constructions in early Indo-European, Cambridge: Cambridge University Press.

Sandfeld, K. 1930, Linguistique balkanique. Paris: Klinck-sieck. (Original 1926: Balkanfilologien. Copenhagen: Luno).

Schaller, H. 1975, Die Balkansprachen. Eine Einführung in die Balkanphilologie. Heidelberg: Carl Winter Universitätsverlag.

Schönig, C. 2003, Turko-Mongolic Relations, in Janhunen, J. (ed.), The Mongolic Languages, London: Routledge: 403-419.

Smyth, H. W. - Messing, G. 1956. Greek Grammar, Cambridge, MA: Harvard University Press: $360-361$.

Thomason, S.G. 200o, Linguistic areas and language history, in Gilbers, D. - Nerbonne, J. - Schaeken, J. (eds.), Languages in Contact, Amsterdam: Rodopi: 311-327.

Thomason, S.G. 2003, Language contact, Edinburgh: Edinburgh University Press.

Trubetzkoy, N.S. 1928, [Proposition 16] Acts of the First International Congress of Linguistics, Leiden: 17-18.

Trubeztkoy, N.S. 1931, Phonologie und Sprachgeographie, «TCLP» 4: 228-234 (published 1971 in Grundzüge der Phonologie, Göttingen: 262-268). 
Tuite, K. 1999, The myth of the Caucasian Sprachbund: The case of ergativity, «Lingua» 108/1: 1-29.

Urban, M. 2007, Defining the linguistic area/league: an invitation to discussion, «Studia Linguistica Universitatis Iagellonicae Cracoviensis» 124: 137-159.

Watkins, C. 1997, Delbrück and the syntax of Hittite and Luvian: predictive power, in E. Crespo - J.L. García Ramón (eds.), Berthold Delbrücky la sintaxis indoeuropea hoy. Actas del Coloquio de la Indogermanische Gesellschaft, Madrid, 21-24 de septiembre de 1994, Madrid-Wiesbaden: Reichert Verlag: 611-630.

Watkins, C. 2001, An Indo-European Linguistic Area and its Characteristics, in A. Aikhenvald - R.M.W. Dixon (eds.), Areal Diffusion and Genetic Inheritance. Problems in Comparative Linguistics, Oxford: Oxford University Press: 44-63.

Weinreich, U. 1958, On the compatibility of genetic relationship and convergent development, «Word» 14: 374-379.

West, M. 1978, Hesiod. Works and Days, Oxford: Oup: 3-13.

West, M.L. 1988, The Rise of the Greek Epic, «The Journal of Hellenic Studies» 108: 151-172.

West, M.L. 1997, West, The East Face of Helicon. West Asiatic Elements in Greek Poetry and Myth, Oxford - New York: Clarendon.

Yakubovich, I. 2010, Sociolinguistics of the Luvian Language, (Brill's Studies in IndoEuropean Languages \& Linguistics 2), Leiden: Brill. 